\title{
Factors Influencing the Fear of Needles among Students of Medicine and Pharmacy
}

\author{
Boban Milovanović, Dušan Tomović, Slobodan M. Janković, Iva Grubor, Ljiljana Nikolić, Miloš \\ Nikolić, Marina Mijajlović, Strahinja Mrvić, Ana Divjak, Andjela Milojević, Jelena Djoković, \\ Andjelka Prokić, Andriana Bukonjić, Marija Sekulić, Vesna Matić, Djordje Vukmirović, Bojan \\ Rakonjac, Tanja Dimitrijević, Nataša Nikolić, Dragutin Jovanović, Jelena Milovanović, Marija \\ Ratković, Nevena Barudžić, Nenad Mladenović, Milan Milutinović, Ana Antanasković, Milena \\ Nikolić
}

University of Kragujevac, Faculty of Medical science, Kragujevac, Serbia

\section{SUMMARY}

Fear of needles can significantly limit professional and social functioning of a person, and is highly prevalent in general population ( $4 \%$ ).

The aim of our study was to reveal risk factors that are associated with fear of needles among healthy university students of medicine and pharmacy.

The study was of a cross-sectional type. In total, 301 students of medicine or pharmacy $(82 \%$ female and $18 \%$ male) attending from 1st to 5th year of study were surveyed at the Faculty of Medical Sciences, University of Kragujevac, Serbia. The students were surveyed using a questionnaires (scales) for assessing the fear of needless, a visual analog scale for self-assessment intensity of the fear of needless, and a general questionnaire with questions about socio-demographic characteristics of the participants. Using a score on the scales as out-come variables, multiple regressions were employed to reveal factors that may influence the fear of needles.

Average values of Blood/Injection Fear Scale, Injection Phobia Scale-Anxiety and Medical Avoidance Survey scores were $7.89 \pm 9.48,4.46 \pm 5.18$ and $89.95 \pm 12.73$, respectively. The following factors affected significantly the score of the scales: course of study, chronic disease in the family, fear of a dentist, smell of the room phobia, sound phobia, score on the Beck's anxiety scale and fear of a situation when medical staff give an injection. The presence of chronic disease in the family was a protective factor, while the other six factors were contributing to the fear of needles.

Fear of needles is more prevalent among the students of pharmacy than among the students of medicine. It is less frequent among students with chronic disease in their family, while fear of dentist, smell of the room phobia, sound phobia, general anxiety and fear from the situation when medical staff give an injection are all factors that predispose students of medicine or pharmacy to develop fear of needles.

Key words: fear of needles, risk factors, university students, medicine, pharmacy

Corresponding author:

Slobodan M. Janković

E-mail: slobodan.jankovic@medf.kg.ac.rs 


\section{INTRODUCTION}

Injections have very important role in the medical care $(1,2)$. It has been estimated that about 12 billion injections and 100 million vaccines are administered annually to children worldwide. This undoubtedly indicates the great importance of recognizing fear of needles, because it can be an obstacle in providing adequate medical care (1). This problem is especially present in specific populations such as diabetics and pregnant women. Among diabetics with a fear of needles, the risk of macrovascular complications is increased, while pregnant women with this fear show a tendency of avoiding regular controls which may include taking samples by using needles $(1,3)$.

Fear of needles, blood and injuries is viewed as unique entity and represents an anxiety disorder. About $4 \%$ of the population in the United States suffers from this specific phobia. According to DSM-IV-TR Classification of Diseases, perception of receiving injection or venous puncture as terrifying stimulus is considered excessive and incomprehensible. A person is intensively anxious and stressed after encountering a phobic object (e.g. blood) or situation (e.g. going to a doctor) (4, 5). Unreasonable and disproportional fear of needles is called belonephobia (6). This type of phobia is often accompanied with vasovagal syncope triggered by the "threatening" stimulus (2).

The phobia of needles, blood and injuries can significantly limit professional and social functioning of a person. This disorder can have serious health consequences such as avoidance of necessary medical care (including medical examinations, life-saving surgical procedures, management of chronic diseases), complications in carrying out parental duties (e.g. problems in perinatal care) and restrictions in choosing potential occupations (e.g. exclusion of health-related professions) $(1,2)$. This phobia is more frequent among the descendents of a phobic person, which points to the genetic basis of this disorder (7).

The patients with this kind of problem often have fainting spells, and manifestations of the fear of needles can be provoked by traumatic event which occurred in the previous five years. The prevalence of fear of needless, blood and injuries is lower among the elderly, while it is higher among females and those with lower educational status $(1,3)$.

Fear of needles usually has its origin in childhood. Among the university students, this phobia is not expected to be encountered if it had not been mani- fested until then. The exception is made by students who had painful experience during administration of injections or had been exposed to a traumatic event (8). In the studies of Domoto PK et al. and Rao et al., it was found that fear of going to the dentist is primarily conditioned by fear of needles and drills in dentist's practice, and it is encountered in $6-51 \%$ of university students $(9,10)$. The results of the study by Yelland $\mathrm{M}$ et al. show that the fear of needles was present in 30.8\% of persons between 18 and 29 years of age (1). Individuals who have this fear should receive special attention of treating physicians.

The aim of our study was to reveal risk factors that are associated with the fear of needles among healthy university students of medicine and pharmacy

\section{MATERIAL AND METHODS}

\section{The study design}

The study was of a cross-sectional type. It was conducted as a one-day survey of a sample of students of medicine and pharmacy from the first to the fifth year of study. The sample consisted of all students who were attending the classes on the survey day. The study was approved by the Ethics Committee of Faculty of Medical Sciences, University of Kragujevac, Serbia.

\section{The study population}

Potential participants of our study were among 1.400 students of the Faculty of Medical Sciences, University of Kragujevac, Serbia. In total, 301 students were present at the Faculty's premises on the survey day, and they comprised the study sample. The students were surveyed using the questionnaires (scales) for assessing the fear of needless, by the visual analog scale for the self-assessment of intensity of the fear of needless and by general questionnaire with questions about socio-demographic characteristics of the participants.

\section{The study variables}

The study outcomes (dependent variables) were scores on the following scales: Blood/Injection Fear Scale (11), Injection Phobia Scale-Anxiety (12) and Medical Avoidance Survey (13).

Blood/Injection Fear Scale (B/IF) (11) consists of two parts. The first part contains questions about 19 
different situations and estimates the extent of avoidance of these situations. The second part of the scale assesses the fear of needles and/or blood and contains 20 questions.

Injection Phobia Scale-Anxiety (IPSanx)(12) is the scale with 18 questions which assess the anxiety during the application of injections or vein punctures.

Medical Avoidance Survey (IPSavo)(13) is a scale with 21 questions where respondents assess their fear related to the avoidance of certain procedures. In this scale, six questions are related to the fear of injections, blood and injuries with the following serial numbers in the original scale: 1, 5, 7, 8, 14 and 15 .

Potentially independent and confounding variables followed in the study were: sex, age, years of study, type of study program (medicine or pharmacy), average grade on studies, experiencing fear in childhood by themselves of by family member(s), environment where a student live (urban/rural), financial status, physical activity, current alcohol use, experience with diseases, mental health, score on the Beck's depressionscale (14), score on the Beck's anxiety scale (15), early alcohol abuse, alcohol dependence, nicotine addiction, presence of some form of mood or somatic disorders, and exposure to a traumatic event in the past.

\section{Statistical analysis}

The data were primarily processed by descriptive statistics. Continuous variables were presented by means $\pm S D$, while the categorical variables were presented by percentages. Normality of the data distribution was tested by Kolmogorov-Smirnov test. If normality was confirmed, a Student's T-test was used to compare the study groups. Otherwise, nonparametric Mann Whitney U test was used. If variables were categorical, we used the $\chi 2$ test to determine differences between the study groups. A multiple regression model was used to identify factors that were related to the fear of injection. The following parameters of analysis were monitored: 95\% confidence interval for B coefficients, $\mathrm{R}$ square and value of $\mathrm{F}$ test. The results were considered significant if probability of null hypothesis was less than 0.05. All calculations were performed by statistical software SPSS for Windows 18.00.

\section{RESULTS}

In total, 301 students were included in the study. Average values of IPSanx, IPSavo and B/IF scale scores were $7.89 \pm 9.48,4.46 \pm 5.18$ and $89.95 \pm 12.73$, respecti- vely. Personal characteristics of the participants and average IPSanx, IPSavo and B/IF scores according to these characteristics are shown in the Table 1, including average score on the Beck's anxiety scale and average score on the Beck's depression scale.

The multiple linear regression analysis using all 24 variables listed in the Table 1 as independent variables in relation to the score of each of these three scales (IPSanx, IPSavo and B/IF) as dependent variables (the "backward" method was employed), resulted with three regression models. All three models are shown in Tables 2, 3 and 4.

From the initial 24 variables, 8 independent variables (course of the study, chronic disease in the family, needle phobia in childhood, fear of the dentist, smell of the room phobia, sound phobia, score on the Beck's anxiety scale (14) and when medical staff gives the injection fear) entered the final multiple regression model with IPSanx score as dependent variables. The excluded variables were: physical activity, score on the Beck's depression scale (15), number of received injections during life, received intramuscular injection, chronic disease, smoking, age of the medical staff who gives the injection, year of study, received intravenous injection, received subcutaneous injection, the last received injection, surgery, sex, average grade, age and needle phobia in the family. $\mathrm{R}$ square was 0.470 , the adjusted $R$ square was 0.452 and the value of $F$ test was $27.030(p=0.000)$.

Final multiple regression model with IPSavo score as a dependent variable, from the initial 24, included 11 independent variables: course of study, average grade, smoking, chronic disease in the family, needle phobia in childhood, needle phobia in the family, fear of the dentist, smell of the room phobia, sound phobia, score on the Beck's anxiety scale (14) and when medical staff gives the injection fear. The excluded variables were: physical activity, score on the Beck's depression scale (15), number of received injections during life, received intramuscular injection, chronic disease, age of the medical staff who gives the injection, year of the study, received intravenous injection, received subcutaneous injection, the last received injection, surgery, sex, average grade and age. However, according to t-test and 95\% confidence interval for B coefficients, B coefficients for 4 of those 11 independent variables were not statistically significant: average grade, smoking, needle phobia in childhood and needle phobia in the family, so we excluded them as factors that are related to the fear of injection. R square was 0.502 , and the adjusted square was 0.479 . Value of $F$ test was $22.160(p=0.000)$. 
Table 1. Average IPSanx, IPSavo and B/IF scores according to the study group characteristics.

\begin{tabular}{|c|c|c|c|c|c|c|c|}
\hline VARIABLE & $\begin{array}{l}\text { NUMBER(\%) } \\
\text { or } \\
\text { MEAN } \pm \text { SD }\end{array}$ & $\begin{array}{c}\text { INJECTION } \\
\text { PHOBIA } \\
\text { ANXIETY } \\
\text { scale score } \\
\text { (mean } \pm \text { SD) }\end{array}$ & $\begin{array}{c}\mathbf{P} \\
\text { value }\end{array}$ & $\begin{array}{c}\text { INJECTION } \\
\text { PHOBIA } \\
\text { AVOIDANCE } \\
\text { scale score } \\
\text { (mean } \pm \text { SD) }\end{array}$ & $\begin{array}{c}\mathbf{P} \\
\text { value }\end{array}$ & $\begin{array}{c}\text { BLOOD/INJECTION } \\
\text { FEAR scale score } \\
\text { (mean } \pm \text { SD) }\end{array}$ & $\begin{array}{c}\mathbf{P} \\
\text { value }\end{array}$ \\
\hline $\begin{array}{c}\text { Sex } \\
\text { Male } \\
\text { Female }\end{array}$ & $\begin{array}{c}54(17.9 \%) \\
247(82.1 \%)\end{array}$ & $\begin{array}{l}5.56 \pm 6.35 \\
8.40 \pm 9.97\end{array}$ & 0.057 & $\begin{array}{l}3.35 \pm 4.10 \\
4.70 \pm 5.37\end{array}$ & 0.140 & $\begin{array}{c}93.96 \pm 9.09 \\
89.07 \pm 13.24\end{array}$ & $0,004^{*}$ \\
\hline Age & $21.58 \pm 1.79$ & 1 & 0.705 & 1 & 0.909 & 1 & 0.277 \\
\hline Year of study & $2.71 \pm 1.24$ & 1 & 0.613 & 1 & 0.501 & 1 & 0.528 \\
\hline $\begin{array}{l}\text { Course of } \\
\text { study } \\
\text { Pharmacy } \\
\text { Medicine }\end{array}$ & $\begin{array}{c}252(83.7 \%) \\
49(16.3 \%)\end{array}$ & $\begin{array}{c}8.83 \pm 10.02 \\
3.06 \pm 2.89\end{array}$ & $0.000^{*}$ & $\begin{array}{l}5.00 \pm 5.41 \\
1.63 \pm 2.22\end{array}$ & $0.000^{*}$ & $\begin{array}{c}88.74 \pm 13.45 \\
96.16 \pm 4.14\end{array}$ & $0.000^{*}$ \\
\hline Average grade & $8.50 \pm 0.80$ & 1 & $0.005^{*}$ & 1 & $0.001^{*}$ & 1 & $0.019^{*}$ \\
\hline $\begin{array}{c}\text { Smoking } \\
\begin{array}{c}\text { yes } \\
\text { no }\end{array}\end{array}$ & $\begin{array}{c}41(13.7 \%) \\
259(86.3 \%)\end{array}$ & $\begin{array}{l}6.05 \pm 6.29 \\
8.13 \pm 9.85\end{array}$ & 0.699 & $\begin{array}{l}3.24 \pm 3.47 \\
4.60 \pm 5.35\end{array}$ & 0.288 & $\begin{array}{l}91.95 \pm 9.88 \\
89.7 \pm 13.09\end{array}$ & 0.788 \\
\hline $\begin{array}{c}\frac{\text { Physical }}{\text { activity }} \\
\text { rarely than } \\
\text { once per week } \\
\text { once per week } \\
2 \text { or } 3 \text { times per } \\
\text { week } \\
\text { daily }\end{array}$ & $\begin{array}{c}92(30.6 \%) \\
86(28.6 \%) \\
96(31.9 \%) \\
27(9 \%)\end{array}$ & $\begin{array}{c}7.61 \pm 9.90 \\
9.28 \pm 8.95 \\
7.98 \pm 10.29 \\
4.11 \pm 4.09\end{array}$ & $0.017^{*}$ & $\begin{array}{l}4.38 \pm 5.23 \\
5.34 \pm 4.91 \\
4.38 \pm 5.61 \\
2.19 \pm 3.54\end{array}$ & $0.003^{*}$ & $\begin{array}{c}90.8 \pm 12.4 \\
87.55 \pm 14.33 \\
90.8 \pm 12.05 \\
93.19 \pm 9.74\end{array}$ & 0.096 \\
\hline $\begin{array}{l}\text { Surgery } \\
\text { yes } \\
\text { no }\end{array}$ & $\begin{array}{l}102(34 \%) \\
198(66 \%)\end{array}$ & $\begin{array}{l}6.85 \pm 8.58 \\
8.42 \pm 9.91\end{array}$ & 0.140 & $\begin{array}{l}3.86 \pm 4.84 \\
4.76 \pm 5.35\end{array}$ & 0.163 & $\begin{array}{l}90.74 \pm 11.51 \\
89.53 \pm 13.35\end{array}$ & 0.762 \\
\hline $\begin{array}{c}\frac{\text { Chronic }}{\text { disease }} \\
\begin{array}{c}\text { yes } \\
\text { no }\end{array}\end{array}$ & $\begin{array}{c}8(2.7 \%) \\
293(97.3 \%)\end{array}$ & $\begin{array}{l}5.63 \pm 6.82 \\
7.95 \pm 9.54\end{array}$ & 0.475 & $\begin{array}{l}2.50 \pm 3.46 \\
4.51 \pm 5.22\end{array}$ & 0.233 & $\begin{array}{c}94.75 \pm 3.85 \\
89.82 \pm 12.86\end{array}$ & 0.630 \\
\hline $\begin{array}{c}\begin{array}{c}\text { Chronic } \\
\text { disease in the }\end{array} \\
\frac{\text { family }}{\text { yes }} \\
\text { no }\end{array}$ & $\begin{array}{l}136(45.3 \%) \\
164(54.7 \%) \\
\end{array}$ & $\begin{array}{c}6.29 \pm 8.03 \\
9.16 \pm 10.38 \\
\end{array}$ & $0.038^{*}$ & $\begin{array}{l}3.48 \pm 4.26 \\
5.25 \pm 5.74 \\
\end{array}$ & $0.010^{*}$ & $\begin{array}{c}92.43 \pm 9.80 \\
87.95 \pm 14.45\end{array}$ & $0.015^{*}$ \\
\hline $\begin{array}{c}\frac{\begin{array}{c}\text { Needle } \\
\text { phobia in }\end{array}}{\text { childhood }} \\
\begin{array}{c}\text { yes } \\
\text { no }\end{array}\end{array}$ & $\begin{array}{l}166(55.1 \%) \\
135(44.9 \%)\end{array}$ & $\begin{array}{c}10.77 \pm 11.29 \\
4.36 \pm 4.66\end{array}$ & $0.000^{*}$ & $\begin{array}{l}5.94 \pm 5.86 \\
2.63 \pm 3.44\end{array}$ & $0.000^{*}$ & $\begin{array}{c}86.36 \pm 14.60 \\
94.36 \pm 8.03\end{array}$ & $0.000^{*}$ \\
\hline $\begin{array}{c}\frac{\text { Needle phobia }}{\text { in the family }} \\
\text { yes } \\
\text { no } \\
\text { I do not know }\end{array}$ & $\begin{array}{c}99(33.2 \%) \\
195(65.4 \%) \\
4(1.3 \%)\end{array}$ & $\begin{array}{c}9.55 \pm 10.43 \\
6.69 \pm 8.59 \\
14.75 \pm 14.36\end{array}$ & $0.012^{*}$ & $\begin{array}{l}5.41 \pm 5.70 \\
3.81 \pm 4.72 \\
6.75 \pm 6.41\end{array}$ & $0.032^{*}$ & $\begin{array}{l}87.79 \pm 14.53 \\
91.39 \pm 11.15 \\
81.75 \pm 24.84\end{array}$ & 0.096 \\
\hline $\begin{array}{l}\text { Fear of the } \\
\text { dentist } \\
\text { almost never } \\
\text { present } \\
\text { quite rarely } \\
\text { present }\end{array}$ & $\begin{array}{l}127(42.2 \%) \\
70(23.3 \%)\end{array}$ & $\begin{array}{l}4.63 \pm 7.07 \\
8.17 \pm 8.62\end{array}$ & $0,000^{*}$ & $\begin{array}{l}2.60 \pm 3.87 \\
4.03 \pm 4.74\end{array}$ & $0.000^{*}$ & $\begin{array}{c}93.76 \pm 8.87 \\
90.96 \pm 12.47\end{array}$ & $0.000^{*}$ \\
\hline
\end{tabular}




\begin{tabular}{|c|c|c|c|c|c|c|c|}
\hline $\begin{array}{c}\text { rarely present } \\
\text { often present } \\
\text { almost always } \\
\text { present }\end{array}$ & $\begin{array}{c}39(13 \%) \\
44(14.6 \%) \\
21(7 \%) \\
\end{array}$ & $\begin{array}{c}10,46 \pm 8,99 \\
9.25 \pm 8.76 \\
19.00 \pm 15.58 \\
\end{array}$ & & $\begin{array}{c}6.38 \pm 5.32 \\
6.05 \pm 4.95 \\
10.19 \pm 7.39\end{array}$ & & $\begin{array}{l}87.64 \pm 12.06 \\
86.30 \pm 13.69 \\
75.52 \pm 19.09\end{array}$ & \\
\hline $\begin{array}{l}\frac{\text { Last received }}{\text { injection }} \\
\text { never } \\
\text { a couple of } \\
\text { months to one } \\
\text { year before } \\
\text { before } 2 \text { to } 10 \\
\text { years } \\
\text { before } 10 \text { years } \\
\text { and more } \\
\text { I do not } \\
\text { remember }\end{array}$ & $\begin{array}{c}10(3.4 \%) \\
86(29.5 \%) \\
106(36.3 \%) \\
72(24.7 \%) \\
18(6.2 \%)\end{array}$ & $\begin{array}{l}4.50 \pm 4.79 \\
7.24 \pm 9.03 \\
8.66 \pm 11.23 \\
7.06 \pm 7.48 \\
10.35 \pm 9.76\end{array}$ & 0.401 & $\begin{array}{l}2.90 \pm 3.18 \\
4.21 \pm 5.21 \\
4.72 \pm 5.41 \\
3.83 \pm 4.47 \\
5.94 \pm 6.68\end{array}$ & 0.665 & $\begin{array}{c}92.80 \pm 8.99 \\
91.21 \pm 11.17 \\
88.24 \pm 14.95 \\
91.53 \pm 11.47 \\
88.33 \pm 12.55\end{array}$ & 0.411 \\
\hline $\begin{array}{l}\frac{\text { Number of }}{\text { received }} \\
\frac{\text { injections }}{\text { during life }} \\
\text { never } \\
\text { less than } 10 \\
\text { times } \\
\text { a couple of } \\
\text { tenth times } \\
\text { more than } 100 \\
\text { times } \\
\text { I do not know }\end{array}$ & $\begin{array}{c}9(3.2 \%) \\
145(50.9 \%) \\
64(22.5 \%) \\
\\
34(11.9 \%) \\
33(11.6 \%)\end{array}$ & $\begin{array}{c}4.22 \pm 4.99 \\
7.66 \pm 9.91 \\
8.86 \pm 10.15 \\
\\
5.71 \pm 5.16 \\
8.03 \pm 8.27\end{array}$ & 0.511 & $\begin{array}{l}2.89 \pm 3.37 \\
4.01 \pm 4.93 \\
5.31 \pm 5.93 \\
\\
3.29 \pm 3.58 \\
4.85 \pm 5.47\end{array}$ & 0.433 & $\begin{array}{c}92.89 \pm 9.53 \\
90.59 \pm 12.52 \\
87.58 \pm 16.49 \\
\\
92.06 \pm 8.6 \\
91.27 \pm 10.47\end{array}$ & 0.878 \\
\hline 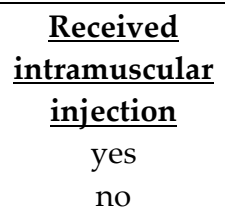 & $\begin{array}{c}257(85.4 \%) \\
44(14.6 \%)\end{array}$ & $\begin{array}{l}7.56 \pm 9.43 \\
9.80 \pm 9.65\end{array}$ & $0.047^{*}$ & $\begin{array}{l}4.22 \pm 5.13 \\
5.84 \pm 5.31\end{array}$ & $0.029^{*}$ & $\begin{array}{l}89.98 \pm 13.08 \\
89.77 \pm 10.57\end{array}$ & 0.315 \\
\hline 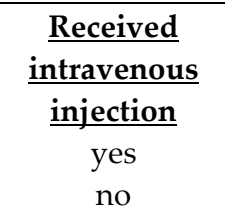 & $\begin{array}{c}68(22.6 \%) \\
233(77.4 \%)\end{array}$ & $\begin{array}{c}6.18 \pm 6.70 \\
8.39 \pm 10.11\end{array}$ & 0.226 & $\begin{array}{l}3.62 \pm 4.19 \\
4.70 \pm 5.42\end{array}$ & 0.238 & $\begin{array}{l}91.63 \pm 10.76 \\
89.46 \pm 13.23\end{array}$ & 0.221 \\
\hline 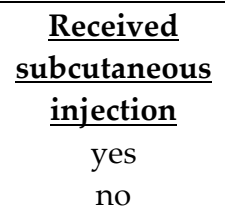 & $\begin{array}{c}74(24.6 \%) \\
227(75.4 \%)\end{array}$ & $\begin{array}{l}8.09 \pm 8.67 \\
7.82 \pm 9.75\end{array}$ & 0.235 & $\begin{array}{l}4.45 \pm 4.68 \\
4.46 \pm 5.35\end{array}$ & 0.470 & $\begin{array}{l}91.12 \pm 11.33 \\
89.57 \pm 13.15\end{array}$ & 0.531 \\
\hline $\begin{array}{c}\text { Smell of the } \\
\frac{\text { room phobia }}{\text { yes }} \\
\text { no }\end{array}$ & $\begin{array}{c}78(25.9 \%) \\
223(74.1 \%)\end{array}$ & $\begin{array}{c}13.94 \pm 12.90 \\
5.76 \text { v } 6.79 \\
\end{array}$ & $0.000^{*}$ & $\begin{array}{l}7.72 \pm 6.22 \\
3.31 \pm 4.22 \\
\end{array}$ & $0.000^{*}$ & $\begin{array}{l}82.33 \pm 15.93 \\
92.65 \pm 10.13\end{array}$ & $0.000^{*}$ \\
\hline $\begin{array}{c}\text { Sound phobia } \\
\text { yes } \\
\text { no }\end{array}$ & $\begin{array}{c}40(13.3 \%) \\
261(86.7 \%)\end{array}$ & $\begin{array}{c}18.40 \pm 13.25 \\
6.27 \pm 7.59\end{array}$ & $0.000^{*}$ & $\begin{array}{c}10.40 \pm 6.82 \\
3.54 \pm 4.21\end{array}$ & $0.000^{*}$ & $\begin{array}{r}75.60 \pm 17.24 \\
92.15 \pm 10.28 \\
\end{array}$ & $0.000^{*}$ \\
\hline $\begin{array}{l}\text { Score on the } \\
\text { Beck`s anxiety } \\
\text { scale }\end{array}$ & $10.41 \pm 9.36$ & / & $0.000^{*}$ & / & $0.000^{*}$ & l & $0.000^{*}$ \\
\hline $\begin{array}{l}\text { Score on the } \\
\text { Beck's } \\
\text { depression } \\
\text { scale } \\
\end{array}$ & $5.65 \pm 5.59$ & / & $0.000^{*}$ & / & $0.000^{*}$ & 1 & $0.000^{*}$ \\
\hline
\end{tabular}




\begin{tabular}{|c|c|c|c|c|c|c|c|}
\hline $\begin{array}{c}\text { Age of the } \\
\text { medical staff } \\
\text { who gives the } \\
\text { injection fear } \\
\text { yes } \\
\text { no }\end{array}$ & $\begin{array}{c}49(16.3 \%) \\
252(86.7 \%) \\
\end{array}$ & $\begin{array}{c}13.51 \pm 12.05 \\
6.79 \pm 8.49 \\
\end{array}$ & $0.000^{*}$ & $\begin{array}{l}7.78 \pm 6.22 \\
3.81 \pm 4.71 \\
\end{array}$ & $0.000^{*}$ & $\begin{array}{l}82.12 \pm 14.41 \\
91.47 \pm 11.81 \\
\end{array}$ & $0.000^{*}$ \\
\hline $\begin{array}{c}\text { When medical } \\
\begin{array}{c}\text { staff gives the } \\
\text { injection fear } \\
\text { yes } \\
\text { no }\end{array}\end{array}$ & $\begin{array}{l}152(50.5 \%) \\
149(49.5 \%)\end{array}$ & $\begin{array}{c}11.82 \pm 11.23 \\
3.85 \pm 4.56\end{array}$ & $0.000^{*}$ & $\begin{array}{l}6.80 \pm 5.81 \\
2.07 \pm 2.93 \\
\end{array}$ & $0.000^{*}$ & $\begin{array}{c}83.79 \pm 14.68 \\
96.23 \pm 5.46\end{array}$ & $0.000^{*}$ \\
\hline
\end{tabular}

Eight dependent variables (course of study, chronic disease in the family, needle phobia in the family, fear of the dentist, smell of the room phobia, sound phobia, score on the Beck's anxiety scale (14) and when medical staff gives the injection fear) entered the final regression model with B/I F scale score as dependent variables. The excluded variables were: physical activity, score on the Beck`s depression scale (15), number of received injections during life time, received intramuscular injection, chronic disease, smoking, age of the medical staff that give the injection, year of the study, received intravenous injection, received subcutaneous injection, the last received injection, surgery, sex, average grade, age and needle phobia in childhood). The $R$ square was 0.468 , and the adjusted $R$ square was 0.450 . Value of $F$ test was $26.888(p=0.000)$.

Table 2. The multiple linear regression model with IPSanx scale score as a dependent variable

\begin{tabular}{c|c|c|c|c}
\hline \hline VARIABLE & $\begin{array}{c}\text { COEFFICIENT } \\
\mathbf{( b )}\end{array}$ & $\begin{array}{c}\text { STANDARDIZED } \\
\text { COEFFICIENT }(\boldsymbol{\beta})\end{array}$ & $\begin{array}{c}\text { P value } \\
\text { (for b) }\end{array}$ & $\begin{array}{c}\text { 95\% CONFIDENCE } \\
\text { INTERVAL } \\
\text { (for b) }\end{array}$ \\
\hline Constant & -2.782 & 1.380 & 0.045 & $-5.501-(-0.064)$ \\
\hline Course of study & 3.124 & 1.177 & 0.008 & $0.805-5.442$ \\
\hline $\begin{array}{c}\text { Chronic disease } \\
\text { in the family }\end{array}$ & -1.944 & 0.899 & 0.032 & $-3.714-(-0.174)$ \\
\hline $\begin{array}{c}\text { Needle phobia in } \\
\text { childhood }\end{array}$ & 2.210 & 0.957 & 0.022 & $0.325-4.095$ \\
\hline $\begin{array}{c}\text { Fear of the } \\
\text { dentist }\end{array}$ & 1.454 & 0.354 & 0.000 & $0.756-2.152$ \\
\hline $\begin{array}{c}\text { Smell of the room } \\
\text { phobia }\end{array}$ & 3.036 & 1.129 & 0.008 & $0.812-5.260$ \\
\hline $\begin{array}{c}\text { Sound phobia } \\
\text { Beck`s anxiety } \\
\text { scale }\end{array}$ & 5.952 & 1.457 & 0.000 & $3.083-8.822$ \\
\hline $\begin{array}{c}\text { When medical } \\
\text { staff gives the } \\
\text { injection fear }\end{array}$ & 4.154 & 0.048 & 0.000 & $0.124-0.314$ \\
\hline \hline
\end{tabular}

When we compare all independent variables which entered these three final regression models, we can see that the same seven independent variables were included in each of all these three different regression models. In the other words, by using three differ rent scales which detect fear of injection, we revealed 7 factors that were always related to the fear of injection, and those are: course of study, chronic disease in the 
family, fear of the dentist, smell of the room phobia, sound phobia, score on the Beck's anxiety scale (anxiety detected by this scale) (14) and fear of the situation when medical staff give an injection. Only one of the seven factors was protective (chronic disease in the family), i.e. it was negatively correlated with the fear of injections in all three models. The other 6 factors were positively correlated with the fear of injections, so we can say that these factors are the contributing ones

Table 3. The multiple linear regression model with IPSAvo scale score as a dependent variable

\begin{tabular}{c|c|c|c|c}
\hline \hline VARIABLE & $\begin{array}{c}\text { COEFFICIENT } \\
(\mathbf{b})\end{array}$ & $\begin{array}{c}\text { STANDARDIZED } \\
\text { COEFFICIENT }(\boldsymbol{\beta})\end{array}$ & $\begin{array}{c}\text { P value } \\
\text { (for b) }\end{array}$ & $\begin{array}{c}\text { 95\% CONFIDENCE } \\
\text { INTERVAL } \\
\text { (for b) }\end{array}$ \\
\hline Constant & 3.793 & 2.814 & 0.179 & $-1.749-9.336$ \\
\hline Course of study & 1.487 & 0.631 & 0.019 & $0.244-2.730$ \\
\hline Average grade & -0.581 & 0.305 & 0.058 & $-1.181-0.020$ \\
\hline $\begin{array}{c}\text { Smoking } \\
\text { the family }\end{array}$ & -1.224 & 0.667 & 0.068 & $-2.539-0.090$ \\
\hline $\begin{array}{c}\text { Needle phobia in } \\
\text { childhood }\end{array}$ & -1.273 & 0.473 & 0.008 & $-2.204-(-0.341)$ \\
\hline \begin{tabular}{c} 
Fear of the dentist \\
\hline $\begin{array}{c}\text { Smell of the room } \\
\text { phobia }\end{array}$
\end{tabular} & 0.963 & 0.518 & 0.064 & $-0.057-1.983$ \\
\hline $\begin{array}{c}\text { Sound phobia } \\
\text { Benic disease in }\end{array}$ & 2.717 & 0.189 & 0.000 & $0.380-1.123$ \\
\hline $\begin{array}{c}\text { Beck anxiety } \\
\text { scale }\end{array}$ & 0.113 & 0.594 & 0.021 & $0.214-2.552$ \\
\hline \hline $\begin{array}{c}\text { When medical staff } \\
\text { fear }\end{array}$ & 2.674 & 0.026 & 0.001 & $1.167-4.267$ \\
\hline \hline
\end{tabular}

\section{DISCUSSION}

Our study showed that the course of study was one of the risk factors which contributed to the fear of injections: students of pharmacy had significantly higher level of fear of injection than students of medicine. Although variations in fear of injections among student of medicine and pharmacy were not studies in other populations, this finding is somewhat in accordance with the study which showed that medical students have less fear of dentist than students of dentistry (10). Taking into account that needle is one of the most important fear-provoking stimulus related to the fear of dentist (9), we suppose that medical students had lower level of fear of injection because during their studies they were exposed to many situations that involve injection procedures, unlike pharmacy students.

Several authors reported previously that individuals with chronic disease(s) have less fear of some medical procedures, including the ones that involve injections $(16,17)$. We came to similar conclusion in our study, since students with at least one member of the family with chronic disease had lower levels of fear of injections. The explanation of this phenomenon might be that people with chronic disease have to adapt to more stressful situations than healthy people and to withstand many painful medical procedures; they do that by using coping as their main strategy (16).

Although many earlier studies found that females are more likely to have needle phobia $(1-3,5$, 
$13,18,19)$, we did not encounter such differences between males and females in our study. The explanation may lie in the fact that participants in our study were students of medicine or pharmacy, so the level and type of education probably were key factors responsible for the absence of difference in needle phobia level among respondents, in regard to their sex. This explanation is supported by findings of some studies that the level of education was inversely correlated with the level of needle phobia $(3,11,18)$.

One study reported that dental anxiety was not related to needle phobia, but that research included population of children from 7 to 11 years old (20). On the contrary, the results of our study showed that students of medicine or pharmacy who have dental anxiety are also very likely to suffer from needle phobia.

Table 4. The multiple linear regression model with B/I F scale score as a dependent variable

\begin{tabular}{c|c|c|c|c}
\hline \hline VARIABLE & $\begin{array}{c}\text { COEFFICIENT } \\
\mathbf{( b )}\end{array}$ & $\begin{array}{c}\text { STANDARDIZED } \\
\text { COEFFICIENT }(\boldsymbol{\beta})\end{array}$ & $\begin{array}{c}\text { P value } \\
\text { (for b) }\end{array}$ & $\begin{array}{c}\text { 95\% CONFIDENCE } \\
\text { INTERVAL } \\
\text { (for b) }\end{array}$ \\
\hline Constant & 103.641 & 1.891 & 0.000 & $99.916-107.366$ \\
\hline Course of study & -3.448 & 1.644 & 0.037 & $-6.687-(-0.210)$ \\
\hline $\begin{array}{c}\text { Chronic disease in } \\
\text { the family }\end{array}$ & 3.164 & 1.255 & 0.012 & $0.692-5.635$ \\
\hline $\begin{array}{c}\text { Needle phobia in } \\
\text { the family }\end{array}$ & -2.515 & 1.235 & 0.043 & $-4.947-(-0.083)$ \\
\hline $\begin{array}{c}\text { Fear of the dentist } \\
\text { Smell of the room } \\
\text { phobia }\end{array}$ & -1.702 & 0.497 & 0.007 & $-2.681-(-0.723)$ \\
\hline $\begin{array}{c}\text { Sound phobia } \\
\text { Beck's anxiety } \\
\text { scale }\end{array}$ & -4.223 & 1.558 & 0.001 & $-10.956-(2.790)$ \\
\hline $\begin{array}{c}\text { give the injection } \\
\text { fear }\end{array}$ & -0.266 & 2.073 & 0.000 & $-0.398-(-0.133)$ \\
\hline \hline
\end{tabular}

Considering that one in four adults reports clinically significant fear of dental injections $(21,22)$ and that the needle and the drill were the most prominent fear-provoking stimuli $(9,10)$, a connection between dental anxiety and needle phobia may be explained by fear of dental injections. In order to decrease recruiting patients with needle phobia, dental office and a room where the injections are given should not be set close to each other, and common waiting room for these two offices should be avoided. Bloodinjection-injury phobia is one of the five subtypes of specific phobia $(5,23-25)$. Some of the studies investigated relations between specific phobia and generalized anxiety disorder and showed that in many cases a specific phobia was associated with generalized anxiety $(5,18,26)$. In accordance with these results, our study also showed that blood-injection-injury phobia was significantly correlated with generalized anxiety, which was measured by the Beck's anxiety scale (14). Taking into consideration these findings some authors suggested certain types of psychological treatments of patients with needle phobia to achieve a decrease in the anxiety level, and therefore to extenuate needle phobia in these patients $(6,12,22,27,28)$. Some other authors even recommended oral premedication with benzodiazepines, or some other anti-anxiety agents to avoid the development of needle phobia in stressful situations, involving blood, injections of injuries $(7,27)$.

It was pointed out previously that specific smell of the room was closely related to the needle phobia (19, 29 ), and our study came to the same conclusion. Specific smell of the room as a provoking factor of needle phobia can be explained by the ability of scents to arouse potent emotional reactions (28). Our study 
confirmed some additional findings from this study that watching and hearing sounds when medical staff prepare syringes can cause needle phobia (19). In order to reduce the incidence of the fear of injections, some architectural and organizational changes should be made in health facilities, separating preparation and administration of injections spatially and/or temporally (19). If this is not possible, nurses should attempt to conceal the preparation of the syringe from the patients and to avoid the sounds which could provoke fear of needles. Besides, the substances with specific smell should be stored in room which is separated and well isolated from waiting room and the room where the injections are administered.
In conclusion, fear of needles is more prevalent among the students of pharmacy than among the students of medicine. It is less frequent among students with chronic disease in their family, due to protective effect of experience with difficult medical situations. On the other hand, fear of dentist, smell of the room phobia, sound phobia, general anxiety (14) and fear of the situation when medical staff give an injection are all the factors that predispose students of medicine or pharmacy to develop fear of needles. Much should be done on removing these factors or attenuating their influence in order to prevent the development of fear of needles, which have serious adverse consequences on health of the affected students and on their future professional success.

* The study was designed and conducted as part of the teaching process in the field of research methodology within the PhD study course

"Clinical and Experimental Pharmacology", Faculty of Medical Sciences, University of Kragujevac, which explains a large number of authors. Teaching professor Slobodan M. Janković 


\section{References}

1. Yelland M, Heathcote K, Ng SK. Fear of needles: Nature and prevalence in general practice. Austra lian Family Physician. 2009;38(3):172-6.

2. Armstrong T, Hemminger A, Olatunji BO. Attentio nal bias in injection phobia: Overt compo nents, time course, and relation to behavior. Behaviour Research and Therapy. 2013;51(6):266-273.

https://doi.org/10.1016/j.brat.2013.02.008

3. Bienvenu OJ, Eaton WW. The epidemiology of blood-injection-injury phobia. Psychol Med. 1998; 28(5):1129-36.

https://doi.org/10.1017/S0033291798007144

4. American Psychiatric Association. Diagnostic and Statistical Manual of Mental Disorders, Fourth Edi tion Text Revision (DSM-IV TR). American Psychia tric Press, Washington, DC (2000)

5. Stinson FS, Dawson DA, Chou SP, et al. The epidemiology of DSM-IV specific phobia in the USA: results from the National Epidemiologic Survey on Alcohol and Related Conditions. Psychological Medicine. 2007; 37:1047-1059.

https://doi.org/10.1017/S0033291707000086

6. Yim L. Belonephobia-a fear of needles. Aust Fam Physician. 2006;35(8):623-4.

7. Sokolowski CJ, Giovannitti JA Jr, Boynes SG. Needle phobia: etiology, adverse consequences, and patient management. Dent Clin North Am. 2010;54(4):731-44.

https://doi.org/10.1016/j.cden.2010.06.012

8. Kleinknecht RA. Acquisition of blood, injury, and needle fears and phobias. Behav Res Ther. 1994; 32(8):817-23.

https://doi.org/10.1016/0005-7967(94)90161-9

9. Domoto PK, Weinstein P, Melnick S, et al. Results of a dental fear survey in Japan: implications for dental public health in Asia. Community Dent Oral Epide miol 1988;16:199-201

https://doi.org/10.1111/j.1600-0528.1988.tb01753.x
10. Rao A, Sequeire PS, Peter S. Characteristics of dental fear amongst dental and medical students. Indian J Dent Res 1997;8:111-4.

11. Kose S, Mandiracioglu A. Fear of blood/injection in healthy and unhealthy adults admitted to a teaching hospital. Int J Clin Pract. 2007;61(3):453-7. https://doi.org/10.1111/j.1742-1241.2006.01150.x

12. Öst LG, Hellström K, Kåver A. One versus five sessions of exposure in the treatment of injection phobia. Behavior Therapy. 1992;23(2):263-281. https://doi.org/10.1016/S0005-7894(05)80385-5

13. Kleinknecht RA, Thorndike RM, Walls MM. Factorial dimensions and correlates of blood, injury, injection and related medical fears: cross validation of the medical fear survey. Behav Res Ther. 1996; 34(4):323-31. https://doi.org/10.1016/0005-7967(95)00072-0

14. Beck AT, Ward CH, Mendelson M, et al. An inventory for measuring depression. Arch Gen Psychiatry 1961; 4: 561-571.

https://doi.org/10.1001/ archpsyc.1961.01710120031004

15. Beck AT, Epstein N, Brown G, Steer RA. An inventory for measuring clinical anxiety: psycho metric properties. Journal of Consulting and Clinical Psychology 1988; 56: 893-897.

https://doi.org/10.1037/0022-006X.56.6.893

16. Olson AL, Johansen SG, Powers LE, et al. Cognitive coping strategies of children with chronic illness. J DevBehavPediatr 1993; 14(4): 217-23.

https://doi.org/10.1097/00004703-199308010-0000

17. Slobodan M. Janković, Dragana Aleksić, Zulfer Bahtijari, et al. Risk factors for severe dental anxiety among medical students. Vojnosanit Pregl 2014; 71(1): 16-21

https://doi.org/10.2298/VSP1401016I

18. Park S, Sohn JH, Hong JP, et al. Prevalence, correlates, and comorbidities of four DSM-IV specific phobia subtypes: results from the Korean 
Epidemio logical Catchment Area study. Psychiatry Res.2013; 209(3):596-603 https://doi.org/10.1016/j.psychres.2012.12.025

19. Nir Y, Paz A, Sabo E, Potasman I. Fear of injections in young adult: prevalence and associations. The American Journal of Tropical Medicine and hygiene. 2003;68(3):341-344.

20. Majstorovic M, Veerkamp JS. Relationship between needle phobia and dental anxiety. J Dent Child (Chic). 2004;71(3):201-5.

21. Deacon B, Abramowitz J. Fear of needles and vaso vagal reactions among phlebotomy patients. J Anxiety Disord. 2006;20(7):946-60. https://doi.org/10.1016/j.janxdis.2006.01.004

22. Heaton LJ, Leroux BG, Ruff PA, Coldwell SE. Computerized dental injection fear treatment: a randomi zed clinical trial.J Dent Res. 2013;92(7 Suppl):37S-42S https://doi.org/10.1177/0022034513484330

23. Kendler KS, Neale MC, Kessler RC, et al. The Interrelationship of Agoraphobia, Social Phobia, Situational Phobia, and Simple Phobia. Arch Gen Psychiatry. 1992;49(4):273-281.

https://doi.org/10.1001/ archpsyc.1992.01820040025003

24. Neale MC, Walters EE, Eaves LJ, et al. Genetics of blood-injury fears and phobias: a population-based twin study. Am J Med Genet.1994;54(4):326-34. PubMed PMID: 7726205. https://doi.org/10.1002/ajmg.1320540411

25. American Psychiatric Association, 1997. Diagnostic and Statistical Mannual of Mental Disorders, 4th ed. Amerian Psychiatric Association, Washington, DC.

26. Marks I. Blood-injury phobia: a review. Am J Psychiatry 1988;145 (1):1207-1213.; Van Houtem CM, Laine ML, Boomsma DI, Ligthart L, van Wijk AJ, De Jongh A. A review and meta-analysis of the heritability of specific phobia subtypes and corresponding fears.J Anxiety Disord. 2013;27(4):379-88. https://doi.org/10.1016/j.janxdis.2013.04.007

27. Hamilton JG. Needle phobia: a neglected diagnosis. J Fam Pract. 1995 Aug;41(2):169-75.

28. Abramowitz EG, Lichtenberg P. Hypnothera peutic olfactory conditioning (HOC): case studies of needle phobia, panic disorder, and combatinduced PTSD.Int J ClinExpHypn. 2009;57(2):18497.

https://doi.org/10.1080/00207140802665450

29. Searing K, Baukus M, Stark MA, et al. Needle phobia during pregnancy. J Obstet Gynecol Neonatal Nurs. 2006;35(5):592-8.

https://doi.org/10.1111/j.1552-6909.2006.00076.x 


\title{
Faktori koji utiču na strah od igle kod studenata medicine i farmacije
}

\begin{abstract}
Boban Milovanović, Dušan Tomović, Slobodan M. Janković, Iva Grubor, Ljiljana Nikolić, Miloš Nikolić, Marina Mijajlović, Strahinja Mrvić, Ana Divjak, Andjela Milojević, Jelena Đoković, Andjelka Prokić, Andriana Bukonjić, Marija Sekulić, Vesna Matić, Đorđe Vukmirović, Bojan Rakonjac, Tanja Dimitrijević, Nataša Nikolić, Dragutin Jovanović, Jelena Milovanović, Marija Ratković, Nevena Barudžić, Nenad Mladenović, Milan Milutinović, Ana Antanasković, Milena Nikolić
\end{abstract}

Univerzitet u Kragujevcu, Fakultet medicinskih nauka, Kragujevac, Srbija

\section{SAŽETAK}

Cilj našeg istraživanja bio je da se otkriju faktori rizika koji su povezani sa strahom od igle među studentima medicine i farmacije.

Ukupno je bio anketiran 301 student medicine ili farmacije ( $82 \%$ žena i 18\% muškaraca) koji pohađaju Fakultet medicinskih nauka Univerziteta u Kragujevcu od prve do pete godine studija. Studenti su anketirani putem upitnika za procenu straha od igle, putem vizuelno-analogne skale za samoprocenu intenziteta straha od igle i opštim upitnikom sa pitanjima o socio-demografskim karakteristikama učesnika.

Prosečne vrednosti skale straha od krvi i injekcije, i skale fobije i anksiozniosti od injekcije i skorova izbegavanja medicinskih ispitivanja su 7,89 $\pm 9,48 ; 4,46 \pm 5,18$ i 89,95 $\pm 12,73$ respektivno. Sledeći faktori značajno utiču na rezultate skala: smer studija, hronična bolest $\mathbf{u}$ porodici, strah od zubara, fobija od mirisa $\mathbf{u}$ prostoriji, fobija od zvuka, rezultat na Bekovoj skali anksioznosti i strah od situacije kada medicinsko osoblje daje injekciju.

Strah od igle je češća među studentima farmacije nego među studentima medicine. Faktori koji predisponiraju da studenti medicine ili farmacije razviju strah od igle su strah od zubara, fobija od mirisa $u$ prostoriji, fobija od zvuka, opšta anksioznost i strah od situacije kada medicinsko osoblje daje injekciju.

Ključne reči: strah od igle, faktori rizika, medicina, farmacija, studenti 